\title{
Yeniden İşlevlendirilmiş Endüstri Yapılarında Mekân Algısı
}

\author{
Zeliha Büşra Eryiğit ${ }^{1}$ \\ ORCID: 0000-0003-3639-2512
}

\author{
Serhat Aniktar 2 \\ ORCID: 0000-0002-7727-5331
}

Öz

İnşa edildikleri dönemde ana işlevleri sağlayan mekânlar, zamanla ihtiyaçları karşılayamamakta ve kullanım dışı kalmaktadır. Dönemin şartlarımın değişmesi ve ilerlemesi ile birlikte özgün işlevini kaybederek atıl duruma düşen endüstri yapılarının yeniden işlevlendirilerek kente kazandırlması gerekmektedir. Endüstri yapıları, kültürel mirasımız olarak korunmalı, sürdürülebilirliği sağlanmalı ve gelecek kuşaklara aktarılmalıdır.

Endüstri yapılarının yeni kimlikleri ile geri kazandırılmaları yoğun bir süreçtir. Dönüştürü̈len yapının yeni işlevinin gerçek anlamda hayat bulabilmesi, yaşama dahil olabilmesi ve benimsenebilmesi için kullanıcısında bulduğu karşıllk oldukça önemlidir. Yeniden işlevlendirilecek mekânın insan üzerinde oluşturduğu algı, tüm boyutları ile değerlendirilerek dönüşümün gerçekleştirilmesi gerekmektedir. Bu sayede yapılar, özgün kimliklerini koruyarak yeni işlevleri ile insanda ve yaşamda karşıllk bulabilecektir.

Yapılan çalışmada endüstri yapılarından dönüştürülerek yeniden işlevlendirilmiş farklı işlevdeki yapıların insan üzerindeki mekân algısı ölçülerek değerlendirilmesi yapılmıştır. Verilen işleve göre katılımoının mekânl; eski ve yeni işlev kapsamında, iç mekân ve cephe bazında, fiziksel ve duygusal olarak algllamasına yönelik bulgulara yer verilmiş ve değerlendirmeler yapılmıştır.

Anahtar Kelimeler: mekân algısı, görsel algı, yeniden işlevlendirme, endüstri yapısı

\footnotetext{
${ }^{1}$ Arş. Gör., İstanbul S. Zaim Üniversitesi, E-mail: zeliha.eryigit@izu.edu.tr

2 Dr. Öğr. Üyesi., İstanbul S. Zaim Üniversitesi, E-mail: serhat.aniktar@izu.edu.tr

idealkent @ C Kent Araştırmaları Dergisi (Journal of Urban Studies)

http://idealkentdergisi.com

Geliş Tarihi Received Date: 30.09.2020 Kabul Tarihi Accepted Date: 14.04.2021
} 


\title{
Space Perception in Re-Functioned Industrial Buildings
}

\author{
Zeliha Büşra Eryiğgit ${ }^{3}$ \\ ORCID: 0000-0003-3639-2512
}

\author{
Serhat Aniktar 4 \\ ORCID: 0000-0002-7727-5331
}

\begin{abstract}
Spaces that provide their main functions during the period they were built cannot meet the needs over time and become out of use. With the change and progress of the conditions of the period, industrial structures that have lost their original function and become idle must be refunctionalized and regained back to the city. Industrial structures should be preserved as our cultural heritage, ensured sustainability and transferred to future generations.

It is an intense process that industrial structures are re-functionalized and regained to the city with their new identities. The response it finds in its users is very important in order for the new function of the transformed building to be included in life and to be adopted. The transformation should be realized by evaluating the perception of the space to be re-functional on the human with all its dimensions. In this way, buildings will be able to find a response in people and life with their new functions while preserving their original identity.

In this study, the perception of space on human beings was quantificationed and evaluated for buildings with different functions, re-functionalized from industrial buildings. According to the given function, the findings regarding the physical and emotional perception of the participant on the basis of the old and new functions, interior and facade, and evaluations were made.
\end{abstract}

Keywords: perception of space, visual perception, re-functioning, industry structure

\footnotetext{
${ }^{3}$ R. A., Istanbul S. Zaim University, E-mail: zeliha.eryigit@izu.edu.tr

${ }^{4}$ Asts. Prof., İstanbul S. Zaim University, E-mail: serhat.aniktar@izu.edu.tr

idealkent @ C Kent Araştırmaları Dergisi (Journal of Urban Studies) 


\section{Giriş}

İnsanlar gündelik yaşamlarını güvenli bir biçimde sürdürmek için "mekân"a ihtiyaç duyar. Mekân, korunma ve sığınma gibi somut ve fiziksel ihtiyaçları karşılamanın yanında aidiyet, güven ve mahremiyet gibi soyut ve duygusal ihtiyaçları da karşılamaktadır. Tüm bu soyut ve somut karakteriyle mekânların insanla olan bağı alg1 yoluyla gerçekleşmektedir (Çetinkaya, 2015, 1). İnsanın içinde bulunduğu mekânı tanımlaması ve anlamlandırabilmesinin ön şartı o mekânı algılamasıdır.

Endüstri yapıları, yapıldıkları dönemin gereksinimlerini karşılamış olsa da günümüzde hızla gelişen ve değişen şartlar sebebiyle kullanım dışı kalmış ve atıl duruma düşmüşlerdir. Endüstri yapılarının yeniden hayata dahil olabilmesi adına günümüzde yeniden işlevlendirme çalışmaları yapılmaktadır.

Endüstri yapılarının dönüşümlerinin başarılı bir şekilde gerçekleşebilmesi, bu yapıların yaşamın içinde yeniden var olabilmesi, insanın algılamasına ve benimsemesine bağlıdır. Her ne kadar mekân somut olarak değişse de soyut açıdan insan ile kurduğu bağ oldukça önem taşımaktadır (Piran, 2016, s. 39).

Endüstriyel işlevden, toplumun ihtiyacı olan yeni işleve dönüştürülecek yapılarda gerçekleşecek mekânsal dönüşümün insan üzerinde oluşturduğu görsel algının fiziksel, algısal, duygusal boyutlarının değerlendirilmesi çalışmanın amacını oluşturmaktadır. Bu kapsamda çalışmanın ilk bölümünde mekân kavramı ve mekân algısı açıklanmış, endüstri yapıları ve yeniden işlevlendirilmesi üzerinde durulmuş ve dönüşen yapıların mekân algısı ele alınmıştır. Tüm bu kavram ve açılamalardan sonra endüstri yapılarının işlevsel dönüşüm nedeniyle mekânda yeniden kurulan mekân-alg1 ilişkisini insan üzerinden değerlendirilmesi anket yöntemi ile yapılmış, bulgulara yer verilmiş ve değerlendirmeler yapılmıştır. Bu çalışmanın; endüstri yapılarından farklı işlevlere dönüştürülen yapıların insan üzerindeki mekân algısı, yeni işlevin benimsenme durumunun ve etkilerinin ölçülmesi; bu tarz dönüşümlerde uygun işleve yönelik çıarımların yapılmasını sağlayarak yeniden işlevlendirme çalışmalarına yol gösterici olacağ düş̧ünülmektedir. 


\section{Mekân Kavramı ve Algısı}

Tarihsel süreç içerisinde insanlar, hayatta kalmak, barınmak, yaşamlarını korunaklı şekilde devam ettirmek için belirli bir kabuğa ihtiyaç duymuştur. Dışarıdan gelebilecek tehlikelere, hava koşullarının uygunsuzluğuna karşı sığınma isteğinin yanı sıra; aidiyet ve mahremiyet sağlayarak kendini güvende hissetme, ihtiyaçları ve ilişkilerini sağlıklı bir şekilde yürütme ve sürdürme gereksinimi insanları bir arayışa yönlendirmiş ve bu durum "mekân" kavramını ortaya çıkarmıştır.

“Mekân" sözlükte "yer, ev, yurt, uzay, uzam" olarak karşllık bulmaktadır. (TDK, 2020). Mekânın tanımı, birçok disiplin ve kuramcı tarafından ele alınmış olup her bir disiplin bu kavramı kendi bakış açılarıyla incelemiştir. Tanyeli, diğer disiplinlerde zorunlu sayılmayan mekânın, mimarlık için zorunlu olduğunu dile getirmektedir. Mekânın, mimarlığın özünü oluşturduğunu vurgulamaktadır: “...mimarlık ürününün bir mekân oluşturmaması düşünülemez. ...Bu nedenle, mimarlık bir mekân yaratma sanatı olarak da tanımlanabilmektedir." (Eczacıbaşı Sanat Ansiklopedisi, 1997, s. 1194)

Mimarlığın temel uğraşı ve temel ürünü "mekân" olması sebebiyle mimari olarak pek çok tanımlama yapılabilmektedir. Mimarlık Sözlüğü'nde mekân, "kişiyi çevreden belli bir ölçüde ayıran ve içinde çeşitli eylemlerini sürdürmesine elverişli olan bir boşluktur" şeklinde tanımlanmıştır (Hasol, 2010, s. 313).

Mimari mekân; kullanıcısının fizyolojik, psikolojik ve toplumsal ihtiyaçlarını karşılayan uzay parçasıdır. (Schulz, 1971, s. 19) Kullanıcının bir mekân içinde gereksinimlerinin karşılanması için, bu mekânın fonksiyonel, fiziksel ve duygusal tüm boyutlarıyla bir bütün olarak algılanması; sonrasında ortaya çıkan olguların tamamının dikkate alınması gerekmektedir.

Kahvecioğlu (1998), mimari mekânın fonksiyonel ve fiziksel boyutlarının ötesinde algısal boyutunun varlığından söz eder ve şu şekilde açıklar; "mimari mekân; çevresinden, duyularla algılanabilirliği ile ifade edilen ortamdır. Buna göre madde olarak var olan sınırlandırıcıların yanında, insanın duyuları ile algılayabileceği 1şık, renk, ses, hava akımı, vb. özelliklerin oluşturduğu, çevresel mekândan ayrılan ortamlar da "mimari mekân" olarak tanımlanabilir." 
Tüm bu tanımlamalar neticesinde "mekân" ve "insan" arasındaki etkileşimin algı aracılığ duğu mekânı tanımlaması ve anlamlandırabilmesi için onu algılayabilmesi gereklidir. "Alg1, duyu organlarımızdan beynimize ulaşan verilerin örgütlenmesi, yorumlanması, anlamlandırılması sürecidir." (Cüceloğlu, 1997, s.98).

Alg1, genel anlamda çevreden gelen bilgileri edinme süreci olarak tanımlanabilmektedir. Mekânın algılanmasında çevreden bilgi edinme sürecinde kullanıcıların hem sosyo-psikolojik özellikleri hem de duyu organları aracılığı ile elde ettiği fiziksel özellikler etkilidir. Sosyo-psikolojik açıdan mekânın "insan" ile etkileşimi özneldir ve kullanıcıların yaş, cinsiyet, meslek, inanç, bilgi, geleneklerine, kültürlerine, deneyimlerine, yaşayışlarına, bireysel sosyal özelliklerine göre şekillenir. Mekânın oran, biçim, renk, doku, malzeme, ses, 1sı, koku... gibi fizyolojik özellikleri duyu organları ile algılanır. Kullanıcıların duyu organlarının nitelikleri mekânın fiziksel olarak algılanmasında oldukça etkilidir (Şekil 1).

\section{MEKANSAL ALGILAMAYI ETKILEYEN FAKTÖRLER}

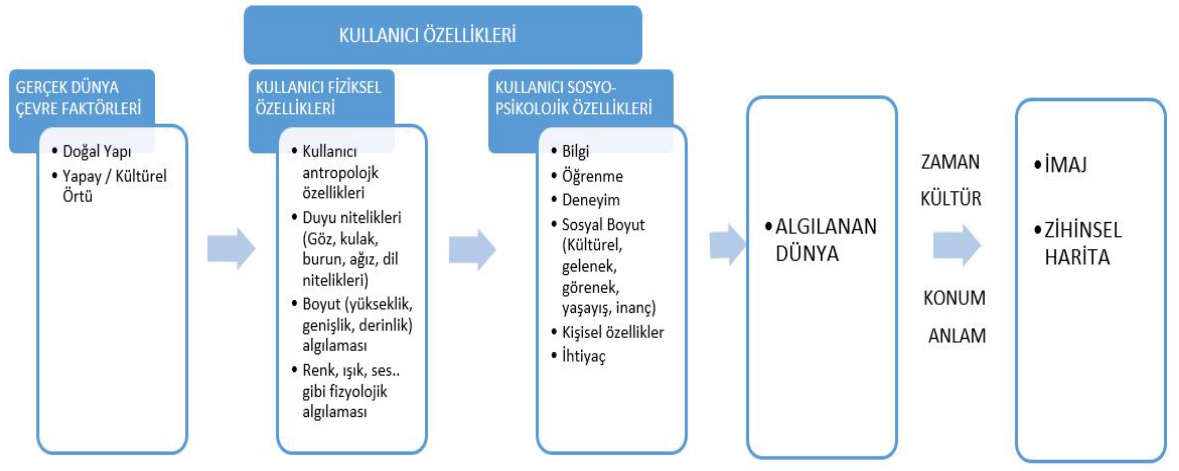

Şekil 1. Mekânsal algılamayı etkileyen faktörler (Erkan, 2007'den aktaran Polatoğlu, 2012, s.20)

Duyular, mekânın algılanmasında öncül basamaklardır. Algılama işlemi göz, burun, kulak, dil ve deri olarak isimlendirilen beş farklı duyu organının uyarılması sonucunda gerçekleşebilir. Fakat görme duyusuyla oluşan görsel algı, baskın duyu olarak kabul edilmektedir. Berger (1998), insanın gördüklerinin dünyasında yaşamakta olduğunu; görsel, fiziksel ve duygusal enerjisinin çoğunu görme eylemine harcadığını belirtmektedir. Çevreden alınan bilgilerin \%80 \% 90'ı göz aracılığılla elde edilmek- 
tedir. Çevre ile kurulan bu görsel iletişim, algılamanın büyük bir bölümünü oluşturmaktadır. Beyinde görsel algı ile ilgili olan kısım diğer tüm algılar için ayrılan yerlerin toplamından daha fazla olması bu sebeptendir (Göler, 2009, s.53). Cüceloğlu (1997) ise birincil ve ikincil duyular olmak üzere ikiye kategoriye ayırdığı duyu organlarında görme duyusunu birincil duyular kapsamina almaktadır.

Görsel algılama süreci, kavramın öncelikle yüzeysel olarak iki boyutlu olarak algılanmasıyla başlamaktadır. Genişlik ve yükseklik içeren iki boyutlu algılama sürecini, derinlik algısıyla birlikte üç boyutlu bir algılama takip eder. Bu aşamada daha detaylı bir algı oluşmaya başlar. Birey, kendisi ile birlikte nesneye veya mekâna bir kimlik kazandırır (Çetinkaya, 2015, s.30). Mekân algısı bağlamında görsel algının değerlendirilmesi mekân tasarımında oldukça önemlidir. Kullanıcının mekânı görsel açıdan algılama sürecinde, mekânı kurgulayan bileşenler ve mekân ögeleri gibi birçok etmen kullanıcının mekânı algılamasında etkin bir rol oynamaktadır. Tasarlanacak mekânın görsel niteliği, mekân kurgusunu oluşturan ölçü-oran, renk, doku, biçim, 1şık-gölge, malzeme şeklinde tanımlanan tasarım ögeleri ile derinden ilişkili olup, oldukça önem arz etmektedir.

\section{Endüstri Yapıları ve Yeniden İşlevlendirilmesi}

İnsan var olduğundan bu yana yaşamını sürdürebilmek amacıyla üretmekte ve ürettiklerini kullanmaktadır. Bu bağlamda geniş ve kapsamlı bir kavram olan endüstri; hammaddeleri yapılı bir hale sokmak için uygulanan eylemlerin ve bu eylemleri uygulamak için kullanılan araç, gereç ve makinelerin tamamıdır (Hasol, 2010, 161). Endüstrileşme süreci ise el ile üretimin, inorganik güç kaynakları ile makineye devredilmesi ve fabrika düzenine geçiş olarak tanımlanabilir (Köksal, 2012, s.18).

18. yüzyıl sonlarında İngiltere'de başlayan Endüstri Devrimi, insanlık tarihindeki önemli kırılma noktalarından biridir. İnsan ve hayvan gücüne dayalı üretim tarzından, makine gücünün baskın olduğu üretim tarzına geçiş ile hizmet ve mamul mal üretimi artmış, üretim modeli ve miktarında ciddi bir gelişme görülmüştür (Yenal, 1999, s.35).

Endüstriye dayalı üretime geçişten önce, insanlar üretimleri evlerde, atölyelerde, el tezgâhlarında daha küçük ölçeklerde gerçekleştirirken; Endüstri Devrimi ile birlikte üretim küçük ve bireysel alanlardan çıkıp, fabrikalarda yapılmaya başlanmıştır. Toplumların yaşayış biçimleri değiş̧- 
miş, geleneksel anlayışın yerini rasyonel anlayış almıştır. Endüstri Devrimi ile teknolojik gelişmelerin etkisiyle hayatın pek çok alanında değişimler ve dönüşümler yaşanmıştır. Mimarlığı doğrudan etkileyen bu teknoloji ve malzemelerdeki gelişmeler ile modern mimarlığın temelleri atılmış ve endüstri mirası kavramını oluşturan endüstri yapıları inşa edilmiştir.

Endüstri Devrimi öncesi üretim yapıları, küçük ölçeklerde taş veya tuğla geleneksel yığma konstrüksiyon ile inşa edilmiştir (Köksal, 2005, s.9). 18. yüzyılda buharlı makinelerin icat edilmesi ile başlayan süreç içerisinde üretim tekniklerinin değişmesi, birbiri ile bağlantılı makinelerin kullanılması, farklı endüstri kollarının ortaya çıkması, üretilen hizmet ve ürün sayısının artması gibi sebeplerle daha geniş ve büyük mekânlara dönüşmüşlerdir. Üretim biçimi, kullanılan makine, araç-gereç ve enerji kaynağı; endüstri yapılarının mimari biçimlenişinin temelini oluşturmuştur. Üretim sürecinde meydana gelen değişimler, doğal bir sonuç olarak endüstri yapılarının mimarisinin de değişmesinde rol oynamıştır. Teknolojik gelişmeler ile endüstri yapılarının biçimlenişinde olduğu gibi biçimin oluşumunda kullanılan malzemelerde de değişiklikler meydana getirmiştir. Demir teknolojisinin ilerlemesi ile dökme demir ve çelik, yeni malzeme olarak ön plana çıkmıştır. Endüstri yapılarının mimarisinde; tasarım esnekliğine kavuşulmuş, kesintisiz ve yüksek mekânlar elde edilmiş, daha hafif strüktürde ve kısa sürede inşa edilme imkânları sağlanmıştır.

Endüstri yapıları her ne kadar yapıldıkları dönemin üretim ihtiyacına hizmet etmiş olsalar da ilerleyen dönemlerde değişen ve gelişen teknoloji karşısında bu yapılara olan ihtiyaç zamanla azalmış, bu yapılar kullanım dışı kalarak atıl duruma düşmüşlerdir. Toplumların belirli dönemlerdeki üretim tarihini, teknolojisini, sosyal, kültürel, ekonomik ve politik yapısını yansıtan endüstri yapıları, kültürel miras olarak korunması gerekli önemli yapılardır. Atıl kalan bu endüstri yapılarının yok olmasını ve zarar görmesini engellemek amacıyla ve bu yapıların korunup, gelecek kuşaklara aktarılmasının sağlanabilmesi adına özellikle 20. yüzyılda endüstri mirası kavramı ortaya çıkmıştır (Alfrey ve Putnam, 1992).

Endüstri mirasının korunması yönünde; Avrupa'da özellikle Fransa, Almanya ve İngiltere gibi ülkeler, aydınlanmayı sanayileşme ile beraber yaşadıkları için 20. yüzyılın ilk yarısı ve öncesinde yapılan endüstri yapılarını 1960'lardan itibaren çeşitli işlevlerle yeniden değerlendirmeye başlamışlardır (Ekinci, 2001, s.39) Makineler ve üretim için tasarlanan 
mekânlar, insanların kullanımına hizmet etmek üzere dönüştürülmüş ve yeniden işlevlendirilmiştir.

Endüstri yapılarının korunması, değer olarak gelecek nesillere aktarılması, toplumun bir parçası haline getirilmesi ve canlandırılması, çevresel koşulların değişmesi ile yapının çevresine yabancılaşarak işlevini yerine getirememesi ile atıl duruma düşmesinin engellenmesi; ekonomik açıdan mevcut yapı stoğunun değerlendirilerek hem ekonomik kazanç hem de enerji açısından yarar sağlanması gibi sebeplerle günümüzde de endüstri yapıları yaygın olarak yeniden işlevlendirilmektedir.

Yeniden işlevlendirilecek endüstri yapılarında uygun işlev seçimi; yapının mimari değerine, konumuna, işlevsel kurgusuna, mekânsal ve hacimsel boyutlarına bağlı olarak şekillenmektedir. Bu işlevlendirmenin başarılı olarak gerçekleştirilebilmesi hem endüstri yapısının kendine özgü niteliklerinin korunması ve sergilenmesi hem de yapının toplum yararına, uzun vadeli, nitelikli bir biçimde kent hayatına dahil olabilmesi ile sağlanabilmektedir (Köksal, 2012, s.19-21).

Bu bağlamda endüstri yapıları ve yeniden işlevlendirilmesine dair yapılan literatür çalışmaları incelenmiştir. Köksal (2005), yaptığı çalışmada Türkiye' deki endüstri mirası için uygun olabilecek belgeleme yöntemi geliştirerek İstanbul'daki endüstri mirası için koruma ve yeniden kullanımlarına dair öneriler getirmiştir. Emre (2008), sanayi yapılarının yeniden işlevlendirme yöntemleri içerisinde İstanbul'dan Silahtarağa Elektrik Fabrikasi/Santral İstanbul ve Şirket-i Hayriye Tersanesi/Rahmi Koç Müzesi dönüşümlerini incelemiştir. Çetinkaya (2015), yaptığ 1 çalışmada yeniden işlevlendirilen endüstriyel mekânların görsel algı değerlendirilmesini İzmir Tarihi Havagazı Fabrikası üzerinden gerçekleştirmiştir. Çalışma kapsamında yapının kent içinde, dış mekânda ve iç mekânda kullanıcı ile kurduğu algısal ilişki gözlem ve anket çalışması ile değerlendirilerek yapılabilecek iyileştirmeler hususunda öneriler getirmiştir. Nartkaya (2016), dünyada ve Türkiye'de eğitim yapısı olarak yeniden işlevlendirilmiş endüstri yapılarını inceleyerek mekân analizlerini gerçekleştirmiştir. Konak (2019), yeniden işlevlendirilerek Seka Kâğıt Müzesi olarak kullanılan yapının iç mekân analizini yaparak başarılı ve eksik yönlerini ortaya koymuştur. Kılıç (2019), Cibali Tütün ve Sigara Fabrikası'nın dönüşümü üzerine tarihsel mekânların heyecan ve memnuniyet faktörleri bağlamında anket yöntemi ile elde ettiği sonuçlara göre kullanıcı algılarını değerlen- 
dirmiş ve yeniden işlevlendirmeye dair öneriler geliştirmiştir. Yeniden işlevlendirilmiş endüstri yapıları ve mekân algısı ilişkisinin incelendiği çalışmamızda çeşitli ülkelerden seçilen endüstri yapısından dönüştürülerek farklı işlevler verilen 7 yapı ele alınmış, anket çalışması ile katılımcılar üzerinde oluşturduğu mekân algısı araştırılmıştır. Yeniden işlevlendirmede farklı işlevlerin katılımcı üzerinde oluşturduğu algısal etkinin k1yaslamalı olarak yapılması; iç mekân, dış mekân, eski-yeni birlikteliğinin katılımcıda uyandırdığ rak ele alınması ve değerlendirmelerinin yapılması çalışmanın özgünlügünü oluşturmaktadır.

\section{Yeniden İşlevlendirilen Yapılarda Mekân Algısı}

Toplumların ve kentlerin değişimi, beraberinde mimariyi ve mekânların değişimini etkilemekte ve mekânların her geçen gün biçim değiştiren kente ve insana yeniden uyum sağlamasını gerektirmektedir. Teknolojik ilerlemeler, gelişen üretim teknolojileri, işlevini kaybetme, çevresel ihtiyaçlara cevap verememe ve günümüzün beklentileri karşılayamama gibi nedenler mekânların yeniden ele alınarak yapılandırılmasını ve yeniden işlevlendirilmesini zorunlu kılmaktadır.

Yeniden işlevlendirme; çevresel, toplumsal, kültürel ve ekonomik gibi birçok nedene bağlı olarak işlevini yitirmiş mevcut yapıların, mekânsal ve kendine has yapısal özelliklerini koruyarak farklı bir fonksiyonla yeniden kullanılması olarak tanımlanabilir. Yapısal olarak varlığını sürdüren bir binanın yapılış amacına dönük olarak kullanılamaması, farklı bir işlevle yeniden değerlendirilmesini zorunlu kılmaktadır. Var olan yapı stoğunun değerlendirilerek doğaya verilen zararın azaltılması, ekonomik açıdan fayda elde edilmesi, kültürel ve tarihsel devamlılık, geçmiş ve gelecek arasında sürekliliğin sağlanması gibi avantajlar bu işlevlendirmeyi gerekli kılmaktadır. İşlevlendirme sürecinde, bina yapısal ve mekânsal özelliklerini dikkate alan analiz ve sorgulamaların yapılması; yeni işlevle insan eylemlerinin karşılanması ve bu bağlamda yaşanabilir mekânlar oluşturulması açısından önemlidir (Aydın ve Yaldız, 2010, s.2-4).

Yeniden işlevlendirme ile mekân; değişmekte, dönüşmekte, yeniden üretilmekte ve kullanıcısı tarafından yeniden algılanmakta ve yeniden anlam kazanmaktadır. Kullanıcı ve mekân arasındaki ilişki ve etkileşimin sorunsuzca işleyebilmesi; yapının var olabilmesi, sürdürülebilmesi, ken- 
tin yaşayan bir parçası olabilmesi, kullanıcısının ihtiyacına cevap verebilmesi, kullanıcısı tarafından benimsenmesi, yapının kendini ifade edebilmesi gibi durumlar için kaçınılmazdır (Piran, 2016, s.36).

Tarihi, kültürel, toplumsal, mimari değerlere sahip olan; yapım tekniği ve strüktürüyle bunları sergileyen yapıların yeniden değerlendirilmelerinde, bir mekânın yeniden yaratılmasından ve yeniden yaşanmasından bahsedilmektedir. Yapının kendine has özelliklerinin kullanıcıya sunulmasını engellemeyecek ve net bir biçimde fiziksel ve psikolojik olarak her aç1dan, her türlü farklı bakış açısından algılanmasını sağlayacak hafiflik, yaratılan mekânda sağlanması amaçlanan konulardan biri olmalıdır. Bu uyum ve esnekliğin mekân ile verilmesine dayalı olan yaklaşımlar pratikte mekân kurgusunda kullanılacak olan mimari eleman, malzeme, doku, renk, 1şık, gölge, plan şemasındaki doluluk, boşluklar ile sağlanabilir (Piran, 2016, s.37). Yeniden kurgulanan mekânda bu tasarım kriterlerinin insanın alg1sına sunulmasında detayların kurgusu oldukça önemlidir. Detaylardaki kurgu, özgün mekânın bütünselliğini kırmadan kullanıcıya yeniden işlevi en olağan haliyle sunmaya ve farklılığ deneyimlemeye imkân sağlar. Yeniden işlevlendirmenin detaylarında kullanıcı ile mekân arasında kurulan ilişkiler üzerinden mekân yeni olarak algılamaya sunulmalıdır.

İşlev değişikliği, toplumun geçmişiyle etkileşim kurmasını sağlayarak tarihi değerlerin kentte yeniden hayat bulmasına da olanak verir (Gazi, Boduroğlu, 2015, s.58) Yapıların, mekânların yeniden işlevlendirilerek kente yeni kimlikleri ile geri kazandırılmaları yoğun bir süreçtir. Bu değişim ve dönüşüm sürecinin en önemli parçası insandır. Mekânın ilk tasarımında kullanıcı olarak birebir yer alan insan, mekânın yeniden üretiminde de yer alacaktır. Bu süreç içerisinde insan; hem üretmekte, hem kullanmakta, hem tüketme, hem de yaşatmaktadır ve bu şekilde kendisi yaşamaktadır. Yeni bir işlevle yeniden değerlendirilen mekânda aslında insan da yeniden var olmaktadır. Yenilenen ve yeniden üretilen kavram ve değerler paralelinde, değişimin insan duygularına, insan algısına hangi yönlerden nasıl etki ettiği oldukça kritik bir noktadır. Bu sebeple mekânın yeniden tasarımında üzerinde durulması gereken en önemli konulardan biridir. Mekândaki değişim ve kurgunun, insanın duygusal tepkileri ve mekânın algılanması üzerinde büyük etkisi vardır. (Osmanlılar, 2012, s.23). Her ne kadar mekânsal olarak somut açıdan fiziki değişimler ön planda olsa da; aslında fiziksel değişimin, soyut açıdan duygusal değişimi beraberinde getirdiği göz ardı edilmemelidir (Piran, 2016, s. 39). 


\section{Anket Çalışması}

\section{Konu ve Amaç}

Anket çalışmasının konusu endüstri yapılarından dönüştürülerek yeniden işlevlenlendirilmiş farklı yapıların kullanıcı üzerindeki mekân alg1sının etkilerinin incelenmesidir. Amaç, endüstri yapılarından farklı işlevlere dönüştürülerek kullanılan yapıların kullanıcı üzerindeki mekân alg1sının ölçülmesi, yeni işlevin kullanıcıda benimsenme durumunun ve etkilerinin ölçülmesi, bu tarz dönüşümlerde kullanıcı açısından en uygun işleve yönelik çıkarımların yapılmasının sağlanmasıdır.

\section{Yöntem}

Anket çalışması iki bölümden oluşmaktadır. İlk bölümde katılımcıların yaş, cinsiyet, öğrenim durumu ve meslek bilgilerini içeren demografik özelliklerine yönelik sorulara yer verilmiştir. İkinci bölümde ise çeşitli ülkelerdeki endüstri yapılarından dönüştürülerek farklı yapı türünde yeniden işlevlendirilmiş 7 adet yapı örneğinin dış ve iç mekân görselleri verilmiş; bu yapıların katılımcı üzerindeki mekân algısını ölçmeye yönelik sorular her yapı türü için ayrı olarak sorulmuştur. Kullanıcılardan açık uçlu, evet-hayır, likert tipi ölçekteki ve çoktan seçmeli çeşitlerindeki sorulara cevap vermeleri istenmiştir. Anket sorularının oluşturulması aşamasında cevaplayanlar için anlaşılması kolay ve yönlendirmeden uzak ifadelerin kullanılmasına özen gösterilmiştir. Anket çalışması, 50 katılımcı ile gerçekleştirilmiştir.

Anket çalışması kapsamında günümüzdeki işlevleri restoran, konut, üniversite, kütüphane, ofis, butik otel ve tiyatro olan 7 farklı işlevdeki yapı seçilmiştir (Tablo 1). Katılımclardan her yapı için sorulan sorulardan önce verilen görselleri detaylı inceleyerek sorulara cevap vermesi istenmiştir. Görseller verildikten sonra 5 adet soru her yapı için ayrı ayrı sorulmuştur. Yapıların günümüzdeki işlevleri hakkında bilgi verilmeyen katılımcılardan ilk soru olarak yapının işlevini tahmin etmeleri istenmiştir. İkinci soru olarak "Yapının endüstri yapısından dönüştürüldügünü bilmeseydiniz eski işlevini tahmin edebilir miydiniz?" sorusu yöneltilmiştir. Üçüncü olarak "Bu yapıya sadece dışarıdan baktığınızda bu yapının yeni işlevini tahmin edebilir miydiniz?" sorusu sorulmuştur. Dördüncü soruda görseli verilen yapıda vakit geçirme isteğini 1'den 5'e kadar puanlamaları istenmiştir. Beşinci soruda ise çeşitli sıfat zıtlıkları verilerek yapının katılımcıda uyandırdığı etki ölçülmüştür. Tüm yapılar için cevaplanan bu sorulardan 
sonra katılımcılardan dönüştürülen yapılardaki işlev beklentisini ölçmek amacıyla "Endüstri yapıları yeniden işlevlendirilecek olsa sizce hangi işlev en uygun olur?" sorusu sorularak anket çalışması tamamlanmıştır.

Tablo 1. Anket çalışması kapsamında katılımcılara verilen endüstri yapısından dönüştürülerek yeniden işlevlendirilmiş yapılar

\begin{tabular}{llll}
\hline & Mevcut işlev & Eski işlev & Konum \\
\hline 1. yapı & Restoran & Tekstil fabrikası & Meksika \\
\hline 2. yapı & Konut & Deri tabakhanesi & Hollanda \\
\hline 3. yapı & Üniversite & Fabrika depolama birimleri & Fransa \\
\hline 4. yapı & Kütüphane & Lokomotif fabrikası & Hollanda \\
\hline 5. yapı & Ofis & Tütün fabrikası & ABD \\
\hline 6. yapı & Otel & Baharat fabrikası & Singapur \\
\hline 7. yapı & Tiyatro/Kültür Yapısı & Tersane & Hollanda \\
\hline
\end{tabular}

\section{Anket Bulguları}

\section{Demografik Bulgular}

Anket çalışması 50 kişi tarafından gerçekleştirilmiş olup katılanların \% 68 kadın, \% 32'si erkektir. Katılımcılar, 18-52 yaş aralığındadır. Katılımcıların çoğunluğu üniversite mezunu olmakla beraber lise ve lisansüstü mezun katılımcılar da bulunmaktadır. Anket çalışması farklı meslek gruplarından kişilerle gerçekleştirilmiştir.

\section{Mekân Algısına Yönelik Bulgular}

\section{Yapının mevcut işlevine yönelik bulgular}

Tablo 2. Katılımcıların mevcut işlevi algılama oranları

\begin{tabular}{lc}
\hline Yapılar & Katılımcıların mevcut işlevi algılama oranları \\
\hline 1. yapı (Restoran) & $\% 94$ \\
\hline 2. yapı (Konut) & $\% 80$ \\
\hline 3. yapı (Üniversite) & $\% 82$ \\
\hline 4. yapı (Kütüphane) & $\% 96$ \\
\hline 5. yapı (Ofis) & $\% 94$ \\
\hline 6. yapı (Otel) & $\% 98$ \\
\hline 7. yapı (Tiyatro/Kültür yapısı) & $\% 96$ \\
\hline
\end{tabular}

Endüstri yapılarından dönüştürülerek kullanılan yapıların yeni işlevini algılamaya yönelik katılımcılara her yapı için "Endüstri yapısından 
dönüştürülerek kullanılan bu yapının yeni işlevi sizce nedir?" sorusu sorulmuştur. Bu sorulara verilen yantlar Tablo 2'de yer almaktadır. Kat1lımcıların büyük çoğunluğu görsellere bakarak yapının mevcut işlevini doğru olarak tanımlayabilmiştir. Mevcut işlevi en iyi algılanan \% 98 oranıyla otel olmuştur (Şekil 2). Bu oranı \% 96 oranlarıyla kütüphane ve tiyatro yapıları izlemektedir. Mekân işlevi algısının en düşük olduğu \% 80 oranıla konut yapısı olmuştur.

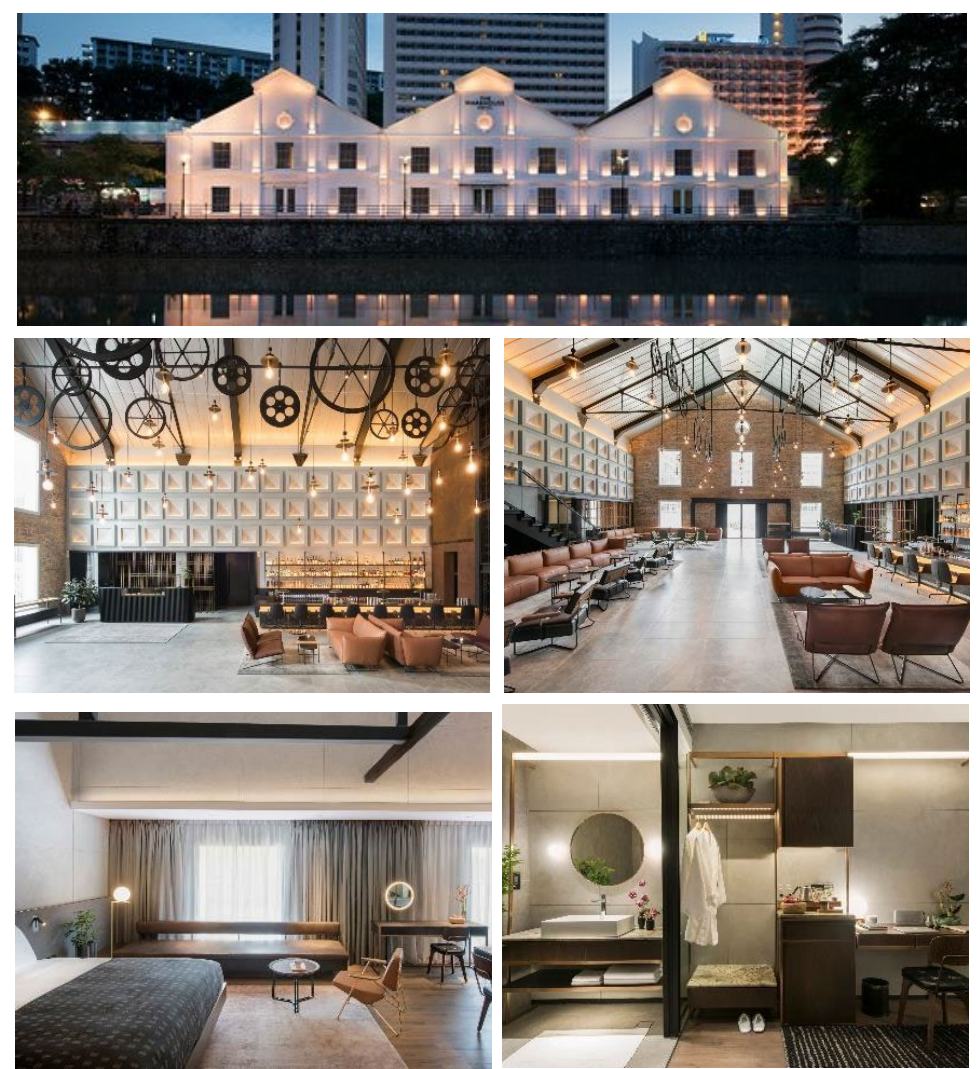

Şekil 2. Butik otel yapısına ait katılımcılara verilen görseller (Url-1)

\section{Yapının eski işlevine yönelik bulgular}

Tablo 3. Katılımcıların eski işlevi algılama oranları

\begin{tabular}{lll}
\hline \multirow{2}{*}{ Yapılar } & \multicolumn{2}{l}{ Katılımcıların eski işlevi algılama oranları } \\
\cline { 2 - 3 } & Evet & Hayır \\
\hline 1. yapı (Restoran) & $\% 18$ & $\% 82$ \\
\hline 2. yapı (Konut) & $\% 32$ & $\% 68$ \\
\hline
\end{tabular}




\begin{tabular}{lll}
\hline 3. yapı (Üniversite) & $\% 58$ & $\% 42$ \\
\hline 4. yapı (Kütüphane) & $\% 36$ & $\% 64$ \\
\hline 5. yapı (Ofis) & $\% 80$ & $\% 20$ \\
\hline 6. yapı (Otel) & $\% 24$ & $\% 76$ \\
\hline 7. yapı (Tiyatro/Kültür yapıs1) & $\% 52$ & $\% 48$ \\
\hline
\end{tabular}

Endüstri yapılarından dönüştürülerek kullanılan yapıların eski işlevini algılamaya yönelik katılımcılara her yapı için "Yapının fabrikadan dönüştürüldügünü bilmeseydiniz eski işlevini tahmin edebilir miydiniz?" sorusu sorulmuştur. Bu sorulara verilen yanitlar Tablo 3'de yer almaktadır. 7 yapıdan 3 tanesinde yüzde olarak "Evet" cevabı, "Hayır" cevabından fazladır. Diğer 4 yapıda "Hayır" cevabı yüzde olarak daha fazladır. En yüksek olarak \% 80 "Evet" oranında mevcut işlevi ofis olan yapının eski işlevi tahmin edilebilmiştir (Şekil 3). Bu oranı \% 58 ile üniversite ve \% 52 ile tiyatro yapısı izlemektedir (Şekil 4-5). Eski işlev tahmininin en düşük olduğu yapı ise \%18 oranıly restoran olmuştur. Bu sonuçlara göre dönüştürülen endüstri yapılarının eski işlevlerinin insanlar tarafından alg1lanma oranının düşük olduğu görülmektedir.

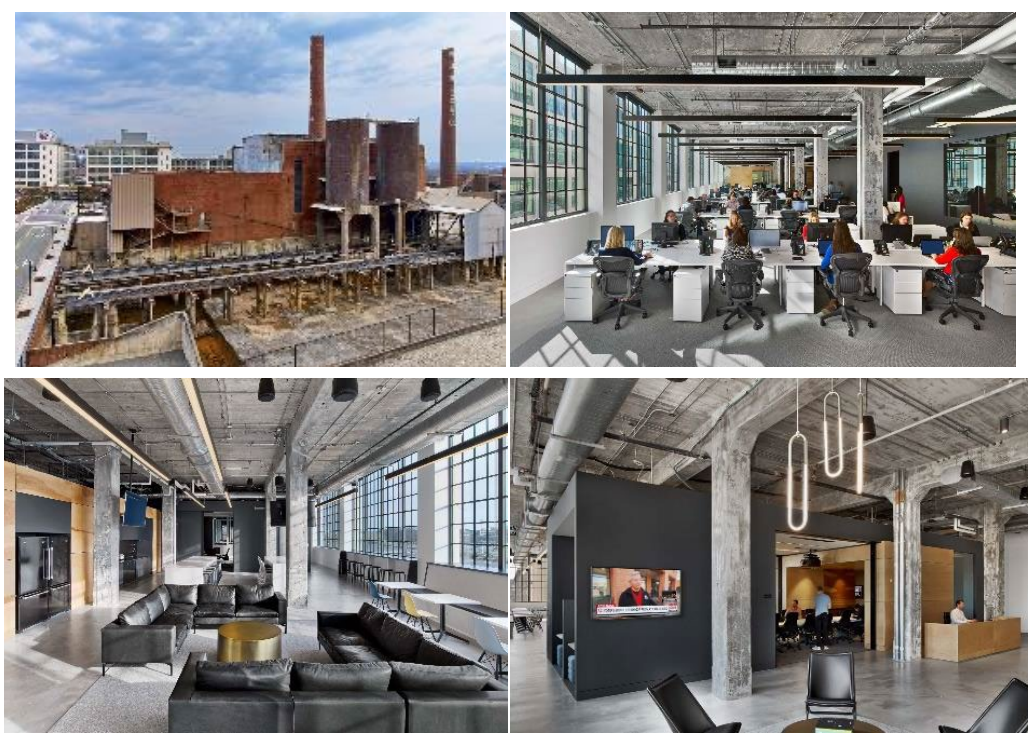

Şekil 3. Ofis yapısına ait katılımcılara verilen görseller (Url-2) 

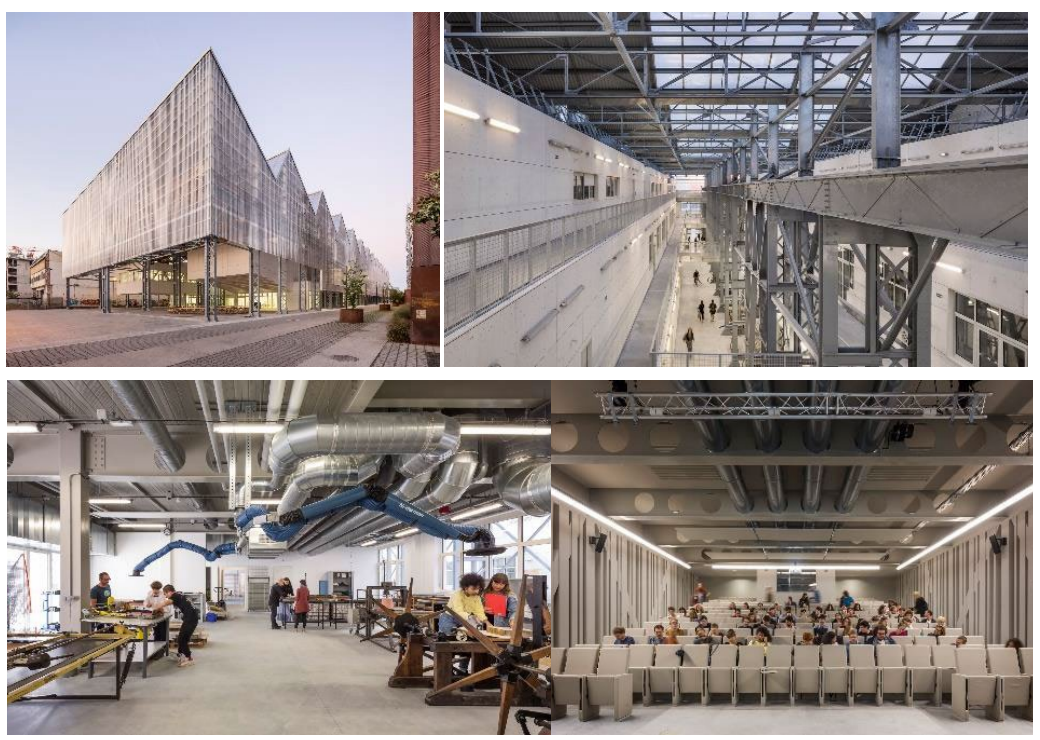

Şekil 4. Üniversite yapısına ait katılımcılara verilen görseller (Url-3)

\section{Yapınm yalnızca cephesine bakarakmevcut işlevini algılamaya yönelik bulgular}

Tablo 4. Katılımcıların yalnızca cepheye bakarak mevcut işlevi algılama oranları

\begin{tabular}{lcc}
\hline \multirow{2}{*}{ Yapılar } & \multicolumn{2}{c}{$\begin{array}{l}\text { Katılımcıların yalnızca cepheye bakarak } \\
\text { mevcut işlevi algılama oranları }\end{array}$} \\
\cline { 2 - 3 } & Evet & Hayır \\
\hline 1. yap1 (Restoran) & $\% 42$ & $\% 58$ \\
\hline 2. yap1 (Konut) & $\% 44$ & $\% 56$ \\
\hline 3. yap1 (Üniversite) & $\% 32$ & $\% 68$ \\
\hline 4. yap1 (Kütüphane) & $\% 34$ & $\% 66$ \\
\hline 5. yap1 (Ofis) & $\% 16$ & $\% 84$ \\
\hline 6. yap1 (Otel) & $\% 50$ & $\% 50$ \\
\hline 7. yap1 (Tiyatro/Kültür yapısı) & $\% 22$ & $\% 78$ \\
\hline
\end{tabular}

Cephe tasarımının yapının işlevini algılamadaki etkisi düşünülerek katılımcılara "Bu yapıya sadece dışarıdan baktığınızda bu yapının yeni işlevini tahmin edebilir miydiniz?" sorusu sorulmuştur. Bu soruya ait yantlar Tablo 4'te yer almaktadır. 7 yapıdan 6' sinda yüzdesel olarak "Hayır" cevabı "Evet" cevabından fazladır. Sonuçlara göre katılımcların büyük çoğunluğu yalnızca cepheye baktıklarında yapıların işlevlerini tahmin edememektedir. Cephe bazında endüstriyel kimliklerini en çok koruyan ofis ve tiyatro yapıları yal- 
nızca cephe görselleri değerlendirildiğinde yüzdesel olarak işlevi en az tahmin edilen yapılar olmuştur (Şekil 3-5). Büyük hacimler ve farklı tasarım kriterleri içeren yapılar olması sebebiyle endüstri yapıları, ne kadar yeniden işlevlendirilse de cephe algısında endüstriyel kimliklerini korumaktadır. Seçilen örneklerde de görüldüğü gibi endüstri yapılarının dönüşümlerinde kendine has özelliklerinin (yapım tekniği, taşıyıcı sistem, malzeme vb.) korunması beklenmekte olup; bu veriler, örneklerin dönüşümlerinin uygunluğunu göstermektedir.
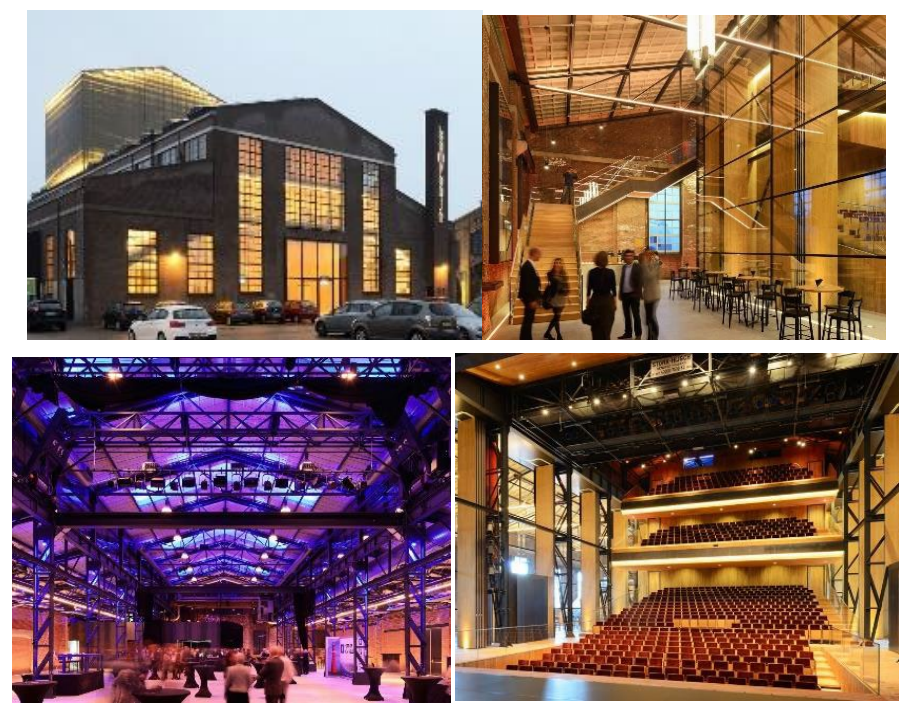

Şekil 5. Tiyatro yapısına ait katılımcılara verilen görseller (Url-4)

\section{Yapıda vakit geçirme isteğine yönelik bulgular}

Tablo 5. Katılımcıların yapılarda vakit geçirme isteğine ait oranlar

\begin{tabular}{|c|c|c|c|c|c|c|}
\hline \multirow[t]{2}{*}{ Yapılar } & \multicolumn{5}{|c|}{$\begin{array}{l}\text { Katılımcıların yapılarda vakit geçirme isteği } \\
\text { puanlarına ait oranlar }\end{array}$} & \multirow[t]{2}{*}{$\begin{array}{l}\text { Puanlamaya } \\
\text { göre siralama }\end{array}$} \\
\hline & 1 & 2 & 3 & 4 & 5 & \\
\hline 1. yap1 (Restoran) & & $\% 2$ & $\% 14$ & $\% 36$ & $\% 48$ & 2. \\
\hline 2. yapı (Konut) & $\% 4$ & $\% 10$ & $\% 18$ & $\% 30$ & $\% 38$ & 4. \\
\hline 3. yap1 (Üniversite) & $\% 6$ & $\% 16$ & $\% 24$ & $\% 26$ & $\% 28$ & 5. \\
\hline 4. yapı (Kütüphane) & & & $\% 10$ & $\% 20$ & $\% 70$ & 1. \\
\hline 5. yapı (Ofis) & $\% 12$ & $\% 12$ & $\% 46$ & $\% 16$ & $\% 14$ & 6. \\
\hline 6. yapı (Otel) & & & $\% 6$ & $\% 28$ & $\% 66$ & 1. \\
\hline 7.yapı (Tiyatro) & $\% 2$ & $\% 2$ & $\% 24$ & $\% 34$ & $\% 38$ & 3. \\
\hline
\end{tabular}


Endüstri yapılarından dönüştürülen mekânlara karşı insanların yaklaşımını, bu tarz yapıları kullanma isteklerini ve verilen örnekler üzerinden mevcut işlevlerden hangilerinin insanlar tarafından daha çok benimsendiğini ölçmek amacıyla katılımcılardan yapılarda vakit geçirme isteklerini 1'den 5'e kadar puanlamaları istenmiştir. Puanlamaya dair veriler Tablo 5 'te yer almaktadır. Puanlamalara göre katılımcılar dönüştürülen yapılardan en çok kütüphane ve otel yapılarında vakit geçirmek istemektedir (Şekil 2-6). En düşük puanlamaya sahip yapı işlevi ise ofistir. Örnekler üzerinden verilen işlevler bazında; bu tarz dönüşümlerde hangi işlevin uygun olacağı hususunda insanlar tarafından kullanım isteği oranları da gözönünde bulundurulması gereken önemli bir faktördür.

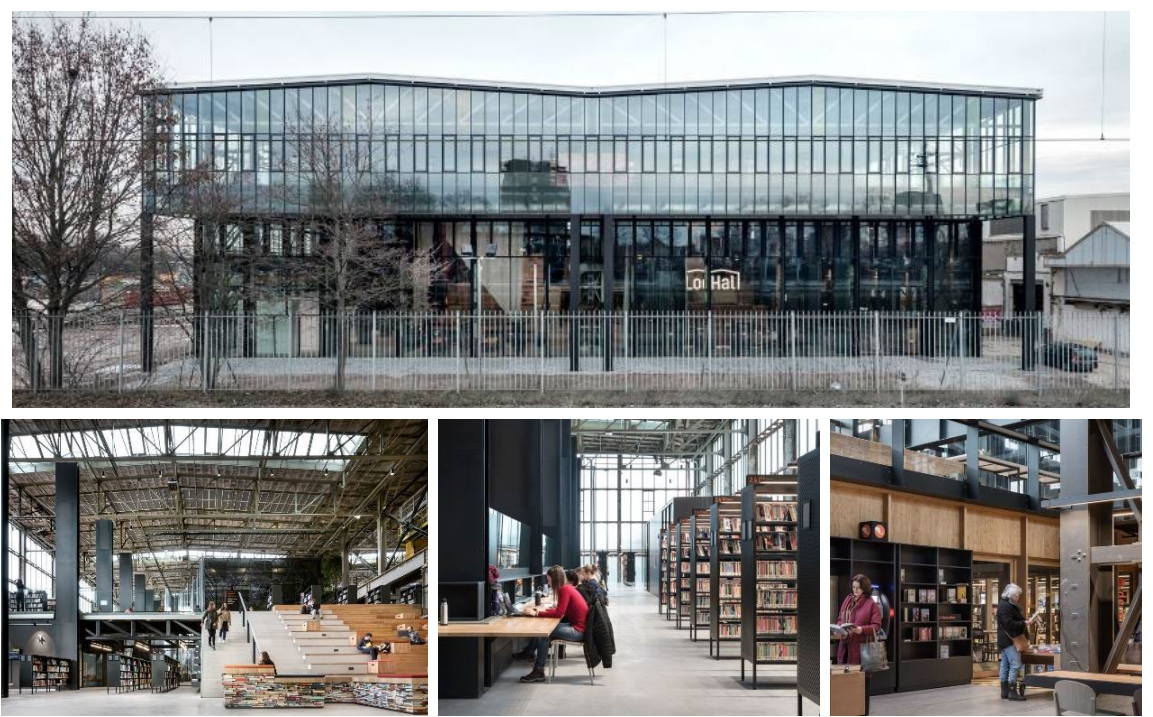

Şekil 6. Kütüphane yapısına ait katılımcılara verilen görseller (Url-5)

\section{Yapıların katılımcılar üzerindeki etkisine yönelik bulgular}

Tablo 6. Yapıların katılımcılarda uyandırdığı etkilere yönelik oranlar

\begin{tabular}{|c|c|c|c|c|c|c|c|c|c|c|c|c|}
\hline \multirow[t]{2}{*}{ Yapilar } & \multicolumn{12}{|c|}{ Yapıların katılımcılarda uyandırdığı etki değerlendirmesi } \\
\hline & Aydınlık & Karanlık & Ferah & Bunaltici & Eğlenceli & Sikici & Gizemli & Okunaklı & $\begin{array}{l}\text { Davet } \\
\text { edici }\end{array}$ & İtici & Sicak & Soğuk \\
\hline 1. yapi (Restoran) & $\% 86$ & $\% 14$ & $\% 88$ & $\% 12$ & $\% 80$ & $\% 20$ & $\% 74$ & $\% 26$ & $\% 98$ & $\% 2$ & $\% 70$ & $\% 30$ \\
\hline 2. yap1 (Konut) & $\% 90$ & $\% 10$ & $\% 86$ & $\% 14$ & $\% 64$ & $\% 36$ & $\% 40$ & $\% 60$ & $\% 82$ & $\% 18$ & $\% 64$ & $\% 36$ \\
\hline $\begin{array}{l}\text { 3. yapı } \\
\text { (Ûniversite) }\end{array}$ & $\% 80$ & $\% 20$ & $\% 64$ & $\% 36$ & $\% 54$ & $\% 46$ & $\% 56$ & $\% 44$ & $\% 70$ & $\% 30$ & $\% 46$ & $\% 54$ \\
\hline $\begin{array}{l}\text { 4. yapı } \\
\text { (Kütüphane) }\end{array}$ & $\% 98$ & $\% 2$ & $\% 98$ & $\% 2$ & $\% 78$ & $\% 22$ & $\% 46$ & $\% 54$ & $\% 94$ & $\% 6$ & $\% 84$ & $\% 16$ \\
\hline 5. yapi (Ofis) & $\% 60$ & $\% 40$ & $\% 52$ & $\% 48$ & $\% 32$ & $\% 68$ & $\% 56$ & $\% 44$ & $\% 42$ & $\% 58$ & $\% 28$ & $\% 72$ \\
\hline 6. yap1 (Otel) & $\% 84$ & $\% 16$ & $\% 90$ & $\% 10$ & $\% 88$ & $\% 12$ & $\% 54$ & $\% 46$ & $\% 98$ & $\% 2$ & $\% 90$ & $\% 10$ \\
\hline 7. yapi (Tiyatro) & $\% 74$ & $\% 26$ & $\% 78$ & $\% 22$ & $\% 70$ & $\% 30$ & $\% 64$ & $\% 36$ & $\% 92$ & $\% 8$ & $\% 84$ & $\% 16$ \\
\hline
\end{tabular}


Bir mekânın algılanabilmesi için insanda uyandırdığı hislerin önemi oldukça fazladır. Mekânın fiziksel ögeleri, insanda çeşitli duyusal etkiler uyandırarak mekân hakkında bazı hisler oluşturmaktadır ve insanlar bunu çeşitli sıfatlarla ifade etmektedir. Bu amaçla katılımclara "Bu yapının sizde uyandırdığı etkiler nelerdir?" sorusu sorularak zıtlık içeren çeşitli sıfat çiftleri verilmiştir: "aydınlık x karanlık", "ferah x bunaltıc" 1 , "eğlenceli x sıkıcı", "gizemli x okunaklı", "davet edici x itici", "sıcak x soğuk". $\mathrm{Bu}$ soruya verilen yanitlar Tablo 6'da yer almaktadır. Verilen cevaplara göre en aydınlık bulunan yapı kütüphane, en karanlık bulunan yapı ofis; en ferah bulunan yapı kütüphane, en bunaltıcı bulunan yapı ofis; en eğlenceli bulunan yapı otel, en sıkıcı bulunan yapı ofis; en gizemli bulunan yapı restoran, en okunaklı bulunan yapı konut; en davet edici bulunan yapı restoran ve otel, en itici bulunan yapı ofis; en sicak bulunan yapı otel, en soğuk bulunan yapı ise ofistir (Şekil 7-8).
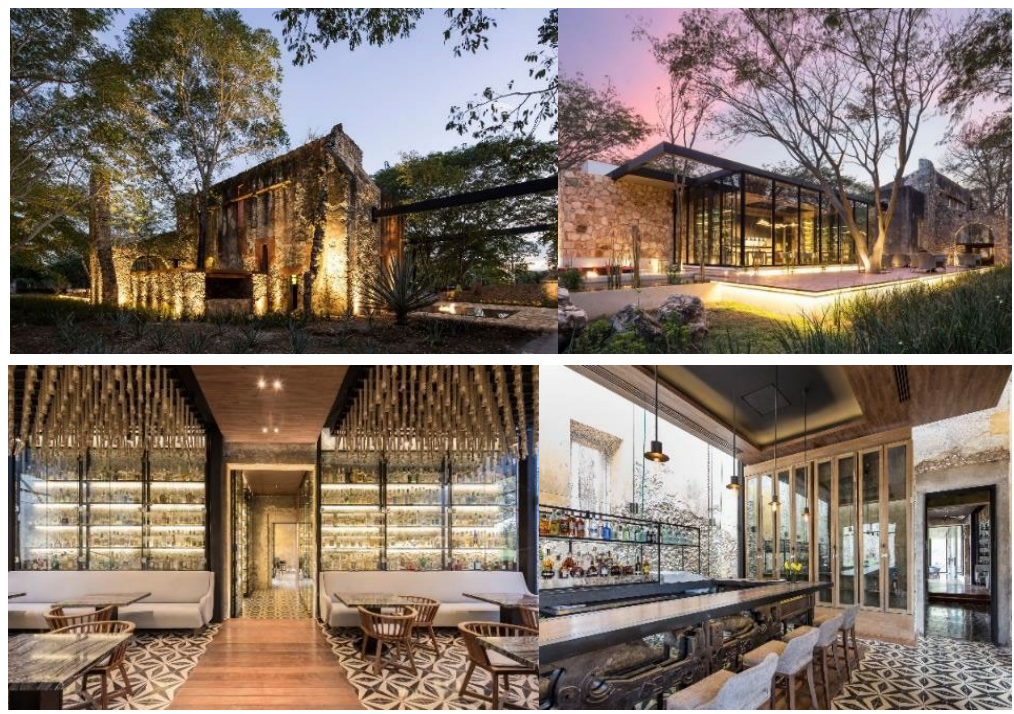

Şekil 7. Restoran yapısına ait katılımcılara verilen görsel (Url-6) 


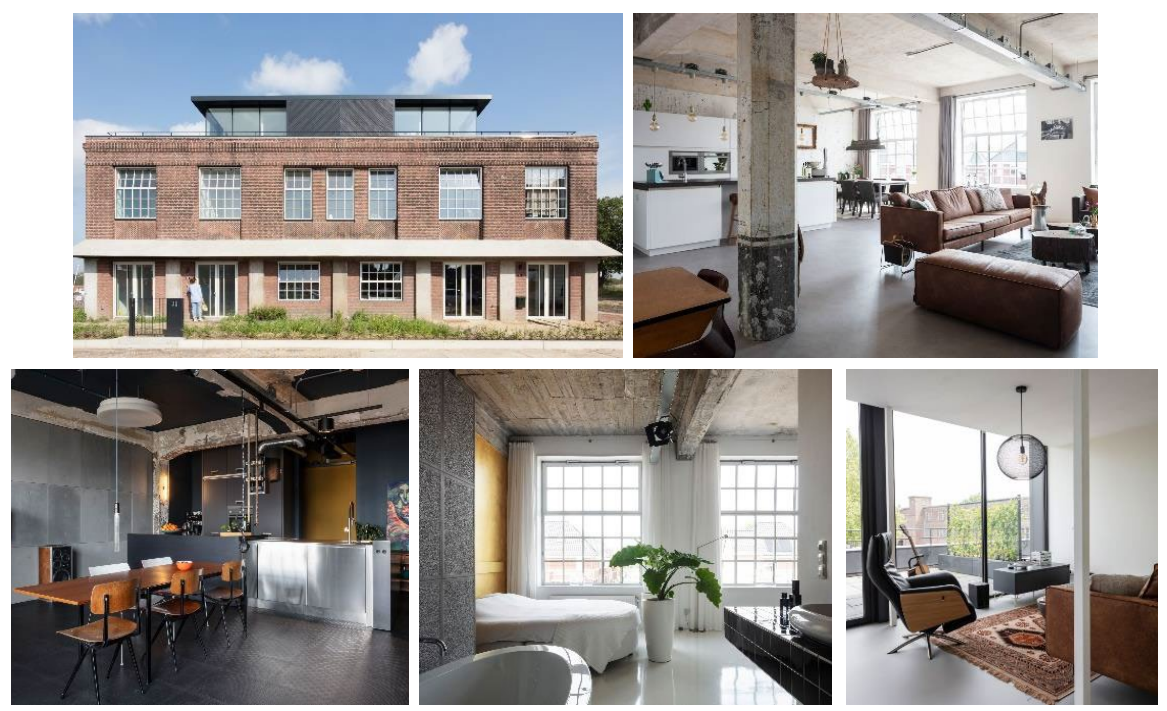

Şekil 8. Konut yapısına ait katılımcılara verilen görseller (Url-7)

\section{Endüstri yapılarnndan dönüştürülecek yapılar için uygun işleve yönelik bulgular}

Tablo 7. Katılımcıların endüstri yapılarından dönüştürülecek yapılar için işlev önerileri
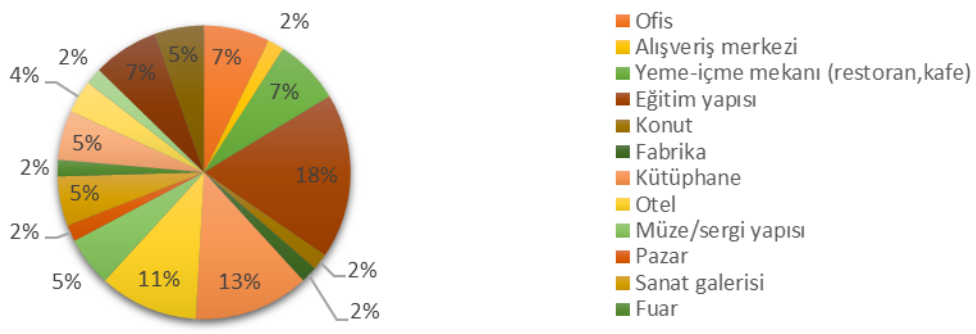

Katılımcılara "Endüstri yapıları yeniden işlevlendirilecek olsa sizce hangi işlev en uygun olur?" sorusu sorularak açık uçlu cevaplamaları beklenmiştir. Burada amaç, mekânın varolması adına insanların dönüştürülen mekânlara yönelik işlev beklentisinin ölçülmesi ve farkındalık oluşturulmasıdır. Bu soruya verilen cevaplar Tablo 7'de yer almaktadır. Katılımcılar, endüstri yapılarının dönüşümü için en uygun işlev olarak \% 18 oranıyla eğitim yapısı cevabını vermişlerdir. Bunu \% 13 oranı ile kütüphane ve \% 11 oranıla otel cevabı takip etmektedir. Katılımcların örneklerde verilen işlevler haricinde farklı işlev önerdikleri de görülmektedir. 


\section{Sonuç}

Soyut ve somut karakteriyle mekân, bireylerin yaşam alanlarını oluştururken; zaman içinde işlev yetersizliği gibi nedenlerle bu karakterini yitirmeye başlar. Bu durumda, mekânı yok etmek yerine, özgün karakterini koruyarak onu yaşatmak üzere yeni bir işlevle kullanımı önerilmektedir. İşlevini yitirerek günümüzün beklentilerine karşılık veremeyen endüstri yapılarının yeni bir işlevle insana sunulması günümüzde oldukça görülen bir durumdur. Bu yeni işlevin hayatta gerçek anlamda karşılık bulabilmesi ve benimsenebilmesi insan algısında karşılı̆̆ını bulması ile mümkündür. Özellikle endüstriyel işlevden, toplumların ortak kullanımına yönelik yeni bir işlev için dönüştürülecek yapılarda gerçekleşecek bu mekânsal dönüşümün insan üzerinde yarattı̆̆ı görsel algının fiziksel, algisal, duygusal boyutları, üzerinde durulması gereken bir husustur.

Yeniden işlevlendirilen endüstri yapılarının mekân algısını ölçmeye yönelik gerçekleştirilen anket çalışmasının bulgularını değerlendirdiğimizde;

- Katılımcıların endüstri yapılarından dönüştürülen mekânların yeni işlevlerini \%80 ve üzeri oranlarda algıladıkları; bu oran ile yüksek bir mekân okumasının gerçekleştiği görülmektedir. Mekânların iç tasarımında tefriş düzenlemelerinin, malzeme, doku, renk, 1şık gibi tasarım ögelerinin ve detay çözümlerinin yeni işleve yönelik bütüncül bir biçimde kurgulanması ve kullanıcıya sunulmasının yeni işlevin doğru algılanmasına katkısını ortaya koymuştur.

- Katılımcıların yapıların özgün işlevlerini tahmin edemedikleri görülmektedir. Bunun nedeni, endüstri işlevi ile yeni verilen işlevin hacimsel ve mekânsal kurgu uyumunun etkisidir (Altınoluk, 1998, s. 22-23) . Büyük hacimli mekânlardan oluşan endüstri yapılarına daha küçük ve tekrar eden birimlerden oluşan yeni işlevler verildiğinde mekânın bütüncül alg1sı bozulmakta ve katılımcı eski işlevi algılayamamaktadır. Ayrıca yapı üzerinde gerçekleşen iç mekân müdahaleleri arttıkça ve mekân bölündükçe yapının tarihi işlevinin etkisi azalmakta; yapı yalnızca arka plan olarak kalmaktadır. Anket çalışması kapsamında katılımcılara verilen görsellerden de okunduğu gibi restoran yapısı, iç mekân düzenlemesinin yoğunluğu ve mekânın fazlaca bölümlendirilmesi sebebiyle eski işlevin en düşük oranda algılandığı yapı olmuştur. Bu sonucu, işlevi gereği daha küçük birimlerden ve tekrar eden sınırlandırıcı elemanlardan oluşan otel ve konut yapıları izlemektedir. Eski işlevin en yüksek oranda algılandı̆̆ı 
yapı ise gerek esnek planlamanın göz önünde bulundurulduğu gerekse endüstri yapısının hacimsel ve strüktürel kurgusunun en iyi okunmasına izin verildiği ofis yapısı olmuştur. Bu bağlamda benzer anlayışın gözetildiği tiyatro ve üniversite yapıları da eski işlevin tahmin edilebilirliği yüksek oranda olan yapılardır. Bu sonuçla, tarihi yapılara kendine has özelliklerinin yansıtılmasını engelleyecek işlevlerin verilmesinin geçmiş ve günümüz arasındaki bağı zayıflattığını görülmektedir. Tarihi değerlerin sürdürülebilmesi adına yeni işlev seçiminin özgün yapının kendine has değerlerini gölgelemeyecek ve zarar vermeyecek şekilde yapılması gerekliliğini ortaya koymaktadır.

- Katılımciların yapıların sadece cephe görsellerine bakarak mevcut işlevi tahmin edemedikleri görülmektedir. Endüstri yapılarının cephe kurguları oldukça karakteristiktir. Çalışma kapsamında seçilen yapılardan cephe bazında endüstriyel karakterini en çok koruyan yapılar olan ofis ve tiyatro yapılarının, yalnızca cephe görsellerinden mevcut işlevinin tahmin edilememe oranı oldukça yüksektir. Bu yapıların endüstri işlevini koruyan özgün cephe yapılarına sahip olmaları ve cephe yüzeylerine müdahale oranlarının minimum düzeyde tutulması mevcut işlevin cephe üzerinden tahmin edilememesine neden olmaktadır. Bu durum endüstri yapılarının yeniden işlevlendirilmesinde yapının özgün karakterini yansitması sebebiyle istenilen ve beklenilen bir unsurdur.

- Anketin yeni işlevin algılanmasına yönelik olan sorularının bulgularını genel olarak değerlendirdiğimizde ise; yeni işlevin iç mekân bazında algılama oranının iç düzenlemeye bağlı olarak değişmekle birlikte çok yüksek oranda olduğu; ancak cephe bazında algılama oranının bu orana kıyasla düşük kaldığı gözlemlenmektedir. Yeni işlev seçiminde hem iç mekân hem de cephe bazında işlev-algı oranın birbirine yakın olacak şekilde düzenlenmesi beklenmektedir. Bu düzenleme yapılırken en kritik nokta ise eski-yeni işlev arakesit algısının sağlanmasında yapının kendine has tarihi özelliklerinden uzaklaşılmaması gerektiğidir.

- Katılımcılar, anket çalışmasında verilen 1-5 puanlama aralığı üzerinden $\% 50$ ve üzeri oranlarda 4 ve 5 puanlarını seçerek bu tarz dönüştürülen yapılarda vakit geçirme isteklerinin çok yüksek oranda olduğunu ortaya koymuştur. Dönüşümlerin katılımcilarda memnuniyet ve benimsenme oranlarının yüksek olması yapının korunması, sürdürülebilirliğinin sağlanması ve insanla bütünleşmesi açısından pozitif bir sonuçtur. Yapıda vakit geçirmeye dair puanlamanın verilen işlev bazında sıralamasına 
bakıldığında ofis işlevinin yüzdesel olarak düşük kaldığı gözlemlenmektedir. Çalışma ortamı ve yüksek verimin beklendiği ofis gibi yapıların katılımcıda uyandırdığı etki oldukça önemlidir. Katılımcının vakit geçirmek istemeyeceği bir yapı, beklenilen işlevsel etkiyi karşılamayacaktır. Yeniden işlevlendirmede seçilecek işlev, katılımcısında beklenilen memnuniyeti ve isteği sağladığı ölçüde başarılı olacaktır.

- Bir mekânin algilanmasında insanda uyandırdığı hisler oldukça önemlidir. İnsan, mekânı algılayarak hislerini çeşitli sıfatlar ile ifade etmektedir. Katılımcılara anket çalışması kapsamında yapıların onlar üzerinde uyandırdığı etkileri ifade etmeleri için zıtlık içeren sıfat çiftleri verilmiştir. "Aydınlık x karanlık" sıfat çiftinden $\% 60$ ve üzeri oranda yapıların "aydınlık" bulunduğu görülmüştür. "Ferah x bunaltıcı" sıfat çiftinden \% 52 ve üzeri oranda yapılar "ferah" olarak tanımlanmıştır. "Eğlenceli x s1kıcı" sıfat çiftinden ofis yapısı hariç \% 54 ve üzeri oranda yapılar "eğlenceli" olarak ifade edilmiştir. "Gizemli x okunaklı" sıfat çiftinden oransal olarak seçimlerin yakın olması ile birlikte yapılar "gizemli" olarak ifade edilmiştir. Yapıların gizemli olarak ifade edilmesi cephe karakterinin iç mekân işlevi hakkında bilgi vermemesi olarak düşünülmektedir. "Davet edici x itici" sıfat çiftinden ofis yapısı dışında \% 70 ve üzeri oranda yapılar "davet edici" olarak nitelendirilmiştir. "Soğuk x sıcak" sıfat çiftinden ofis ve üniversite yapıları hariç \% 64 ve üzeri oranlarda yapılar sıcak olarak ifade edilmiştir. Genel olarak yapılar "aydınlık, ferah, eğlenceli, gizemli, davet edici ve sıcak" sıfatları ile nitelendirilmiştir. Katılımcılar, ofis yapısı için 6 sıfat çiftinden 5'inde olumsuz sıfatı seçmiştir. Otel ve kütüphane yapıları ise katılımcılarda en olumlu sıfatlar ile ifade edilen yapılar olmuştur. Dönüşüm için seçilen işlevin insanlar üzerindeki etkisi, bu işlevin insanlar tarafından benimsenerek yapının hayata dahil olabilmesi adına çok önemlidir. Endüstri yapılarından dönüştürülen yapılarda en çok tercih edilen işlevlerden biri olan ofis, katılımcılarda en olumsuz hisler bırakan yapı olmuştur. Bu durumun çalışan insanlar üzerinde etkisi, yeniden işlevlendirmede ofisin uygun seçim olmadığını ve çalışma eylemini olumsuz etkileme hususunu düşündürtmektedir.

- Mekân insan algısını uyarmakta olup mekân üzerine yapılan çalışmalar, analizler insan olmadan, insan ve mekân bağlantısı oluşturulmadan ele alınmamalıdır. İnsan, istek ve görüşleri gözardı edilerek tasarlanmış mekânlarda ilişki ve etkileşimler sekteye uğramaktadır (Piran, 2016, s.53). İnsanın, dönüştürülen mekânlar hususunda beklentilerini ölçmek 
amacıyla anket çalışması kapsamında son soru olarak katılımcılardan endüstri yapılarından dönüştürülecek yapılar için uygun işlev önerisi sorgulanmıştır. Katılımcıyı bu tarz dönüştürülen yapılar için yeni işlev hususunda düşündürtmek ve beklentilerinin ne olduğunun ölçülmesi, verilecek işlevlerde tasarımcı ve katılımcı arasında ilişkinin sağ lıklı bir biçimde oluşturulmasını ve mekâna yansıtılmasını sağlayacaktır. İnsan gereksinimlerine bağlı oluşturulacak yeni mekânlar için insandan bağımsız şekilde çalışılmaması mekânın oluşumunu güçlendirecektir. Ayrıca dönüştürülen yapılar için insan katılımının sağlanması ve onu odak noktasına alması katılımcılarda farkındalık oluşturacak ve bu hususta talep etmesini sağlayacaktır.

Anket çalışmasının sonuçları doğrultusunda dönüştürülen endüstri yapılarının yeni işlevlerinin özellikle iç mekân bazında insanlar tarafından algılandığı, bu tarz dönüşümlerde verilen işlevin uygunluğuna göre dönüşümün desteklendiği ve benimsendiği görülmektedir. Yapılan bu çalışmanın endüstri yapılarının işlevsel dönüşüm nedeniyle mekânda yeniden kurulan mekân-algı ilişkisini insan üzerinden değerlendirilmesi yap1larak, gelecekte yapılacak yeniden işlevlendirme çalışmalarına katkı sağlayacağı düşünülmektedir. 


\section{Extended Abstract}

\section{Space Perception in Re-Functioned Industrial Buildings}

\author{
Zeliha Büşra ERYİĞITT \\ ORCID: 0000-0003-3639-2512
}

\author{
Serhat ANIKTAR \\ ORCID: 0000-0002-7727-5331
}

People need "space" to continue their daily life safely. Space, besides providing concrete and physical needs such as protection and shelter, it also provides abstract and emotional needs such as belonging, trust and privacy. The connection of the space, which has all these abstract and concrete features, with human beings is realized through perception. The prerequisite for people to define and make sense of the space they live in is their perception of the space.

Although the industrial buildings provided the requirements of the period in which they were built, they have become out of use and idle due to rapidly developing and changing conditions. Nowadays, re-functionalization studies are carried out in order for industrial buildings to be included in life.

The successful transformation of industrial buildings and the re-existence of these buildings in life depends on human perception and adoption. Although the place changes in concrete terms, its connection with the human in the abstract sense is very important.

The aim of the study is to evaluate the physical, perceptual and emotional dimensions of the visual perception created by the spatial transformation that will take place in buildings that will be transformed from an industrial function to a new function that society needs. In this context, the evaluation of the spaceperception relationship, which was re-established in the space due to the functional transformation of industrial buildings, was made with a questionnaire method.

In the survey study, transforming from industrial buildings in various countries; the exterior and interior visuals of 7 different functional buildings, which are restaurant, residence, university, library, office, boutique hotel, and 
theater, are given. Participants were asked to answer the questions after examining the images in detail. The participants, who were not informed about the current functions of the buildings, were asked to predict the function of the building as the first question. As the second question, "If you did not know that the building was transformed from industrial building, could you guess its former function?" has been asked. As the third question, "When you look at this building only from the outside, could you guess the new function of this building?" has been asked. In the fourth question, they were asked to score from 1 to 5 for the desire to spend time in the building given the visual. In the fifth question, giving various adjective contrasts, effect of the building on the participant was measured. After these questions answered for all buildings, in order to measure the function expectation of the participants in the transformed buildings; "What do you think would be the most appropriate if industrial buildings were to be re-functionalized?" the survey was completed by asking the question.

When the findings of the survey are evaluated;

- It's seen that: the participants perceive the new functions of spaces converted from industrial buildings at a rate of $80 \%$ and above. In the interior design of the spaces, the furnishing arrangements, design elements such as material, texture, color, light and the holistic construction of detail solutions for the new function and their presentation to the user has revealed the contribution of the correct perception of the new function.

- It is seen that the participants cannot predict the original functions of the buildings. When industrial buildings consisting of large spaces are given new functions consisting of smaller and repetitive units, the holistic perception of the space deteriorates and the participant cannot perceive the old function. In addition, as the interior space interventions on the building increase and the space is divided, the effect of the historical function of the building decreases.

- Since the facades of industrial buildings are very characteristic, it is seen that the participants cannot predict the new function by looking only at the facade images of the buildings.

- When we evaluate the findings of the questions regarding the perception of the new function in general; although the perception rate of the new function on the basis of the interior changes depending on the interior arrangement, it has been observed that it is very high. However, it is observed that the perception rate on the facade is low compared to this rate. While making this arrangement, the most critical point is that in providing the perception of the old-new 
function intersection, it is necessary not to distract from the unique historical features of the building.

- Participants chose 4 and 5 points at the rates of $50 \%$ and above over the 1 5 scoring range given in the survey study and revealed that their desire to spend time in such transformed buildings was very high. High rates of satisfaction and adoption of conversions among participants; it is a positive result in terms of protecting the building, ensuring its sustainability and its integration with the human.

- Participants were given oppositional adjective pairs to express the effects of buildings on them within the scope of the survey study. Generally, the buildings are described as "bright, spacious, fun, mysterious, inviting and warm". The effect of the function chosen for transformation on people is very important for the building to be embraced by people and to be included in the life.

- Participants answered the educational building with $18 \%$ as the most appropriate function for the transformation of industrial buildings.Making the participant think about the new function for such transformed buildings and measuring what their expectations are, will ensure a healthy relationship between the designer and the participant in the functions to be given and reflecting them to the space.

In line with the results of the survey study, it is seen that the new functions of the transformed industrial buildings are perceived by people, especially on the basis of interior spaces, and the transformation is supported and adopted according to the suitability of the function given in such transformations. It is thought that this study will contribute to the future re-functioning studies by evaluating the space-perception relationship re-established in the space due to the functional transformation of industrial buildings.

\section{Kaynakça/References}

Altınoluk, Ü. (1998). Binalarn Yeniden Kullanımı. İstanbul: YEM Yayınları.

Alfrey, J. ve Putnam, T. (1992). The Industrial Heritage Managing Resources And Uses. Londra: Routledge Publishing.

Aydın, D. ve Yaldız, E. (2010). Yeniden Kullanıma Adaptasyonda Bina Performansının Kullanıcilar Üzerinden Değerlendirilmesi. METU Journal of the Faculty of Architecture, 27(1), 1-22.

Berger, A. A. (1998). Seeing is believing: An introduction the visual communication. Kaliforniya: Mayfield Publishing.

Cüceloğlu, D. (1997). İnsan ve Davranışı: Psikolojinin Temel Kavramları. İstanbul: Remzi Kitabevi. 
Çetinkaya, Ç. (2015). Yeniden işlevlendirilen endüstriyel mekânların görsel algı değerlendirmesi: İzmir Tarihi Havagazı fabrikası. (Doktora Tezi). YÖK Ulusal Tez Merkezi. Ege Üniversitesi, Fen Bilimleri Enstitüsü, İzmir.

Eczacıbaşı Sanat Ansiklopedisi (1997). YEM Yayınları, s. 1194, İstanbul

Ekinci, O. (2001). Endüstri mirasının korunması. İstanbul Dergisi, 39, İstanbul

Emre, Ş.B. (2008). Sanayileşme ve sanayi yapılarının yeniden işlevlendirilmesinin İstanbul'dan Örnekler Üzerinde Analizi, (Yüksek Lisans Tezi). YÖK Ulusal Tez Merkezi. M.S.G.S.Ü., Fen Bilimleri Enstitüsü, İstanbul.

Gazi A. ve Boduroğlu E. (2015) İşlev değişikliğinin tarihi yapılar üzerine etkileri “Alsancak Levanten Evleri Örneği”". MEGARON, 10(1), s.57-69

Göler, S. (2009). Biçim, renk, malzeme, doku ve ışı̆̆ın mekân algısına etkisi. (Yüksek Lisans Tezi). YÖK Ulusal Tez Merkezi. MSGSÜ, Fen Bilimleri Enstitüsü, İstanbul.

Hasol, D. (2010). Ansiklopedik Mimarlı Sözlü̈̆̈̈. İstanbul: YEM Yayınları.

Kahvecioğlu, H. L. (1998). Mimarlıkta imaj: Mekânsal imajın oluşumu ve yapısı üzerine bir model.. (Doktora Tezi). YÖK Ulusal Tez Merkezi, İ.T.Ü. Fen Bilimleri Enstitüsü, İstanbul.

Kılıç, E. (2019). Yeniden işlevlendirilen endüstri mirası yapılarında heyecan ve memnuniyet faktörleri: Cibali Tütün Ve Sigara Fabrikası örneği, (Yüksek Lisans Tezi), YÖK Ulusal Tez Merkezi, Gazi Üniversitesi, Fen Bilimleri Enstitüsü, Ankara.

Konak, N. (2019). Yeniden işlevlendirme kapsamında bir endüstriyel miras örneği olan Seka Kâ̆̆gt Müzesi'nin İç Mekân Analizi. Yüksek Lisans Tezi. YÖK Ulusal Tez Merkezi, Kocaeli Üniversitesi, Sosyal Bilimler Enstitüsü, Kocaeli.

Köksal, G. (2005). İstanbul'daki endüstri mirası için koruma ve yeniden kullanım önerileri, (Doktora Tezi). YÖK Ulusal Tez Merkezi. İ.T.Ü. Fen Bilimleri Enstitüsü, İstanbul.

Köksal, G. (2012). Endüstri mirasını koruma ve yeniden kullanım yaklaşımı. Güney Mimarlik Dergisi, 8, 18-23.

Nartkaya, E. (2016). Eğitim yapısı olarak yeniden işlevlendirilmiş endüstri yapılarında mekân analizi. Yüksek Lisans Tezi. Yök Ulusal Tez Merkezi. Karabük Üniversitesi, Fen Bilimleri Enstitüsü, Karabük.

Osmanlilar, C. (2012). Reflectance of Change within Space and the State of Human Sensation through Adaptive Re-Use of Old Spaces. (Yüksek Lisans Tezi). YÖK Ulusal Tez Merkezi. Doğu Akdeniz Üniversitesi, Lisansüstü Eğitim Öğretim ve Araştırma Enstitüsü, KKTC.

Piran, D. (2016). Endüstri yapılarının yeniden işlevlendirilmesi. (Yüksek Lisans Tezi). YÖK Ulusal Tez Merkezi. MSGSÜ, Fen Bilimleri Enstitüsü, İstanbul.

Polatoğlu, Ç. (2012). Mimarlıta görsel etki değerlendirme yöntem ve teknikleri. İstanbul: YTÜ Yayınları.

Schulz, N.C. (1971). Existance, Space \& Architecture, London: Studio Vista.

Türk Dil Kurumu (2020). Türkçe Güncel Sözlük, (https://sozluk.gov.tr)

Yenal, O. (1999). Ulusların zenginliği ve uygarlı̆̆ı-eğitim boyutu. Ankara: İş Bankası Kültür Yayınları. 